\title{
Assessing levels, trade-offs and synergies of landscape services in the Iranian province of Qazvin: towards sustainable landscapes
}

\author{
Asef Darvishi · Maryam Yousefi · Naghmeh Mobarghaee Dinan • \\ Per Angelstam (D)
}

Received: 14 December 2020/ Accepted: 9 September 2021 / Published online: 1 October 2021

(C) The Author(s) 2021

\begin{abstract}
Context Evidence-based knowledge is crucial for place-based knowledge production and learning towards sustainable landscapes through stewardship and integrated spatial planning.

Objectives We focus on the landscape service concept as a tool, and three fundamental challenges for its use: (1) how to monitor benefits provided by different landscapes; (2) to demonstrate trade-offs and synergies among benefits in a landscape; and (3) to discuss how to incorporate results from analyses into landscape stewardship and planning.

Methods As a case study we chose the Iranian Qazvin province with diverse natural and anthropogenic landscapes, and top-down societal steering. Five landscape services (water yield, water regulation, pollination, actual net primary production (NPPact)
\end{abstract}

A. Darvishi $(\triangle) \cdot$ M. Yousefi · N. M. Dinan Department of Environmental Planning and Design, Environmental Sciences Research Institute, Shahid Beheshti University, 1983969411 Tehran Iran e-mail: Asefdarvishi1980@gmail.com

M. Yousefi

e-mail: yousefi.myb@gmail.com

N. M. Dinan

e-mail: n_mobarghei@yahoo.com and social-cultural connectivity) were assessed and compared.

Results All landscape services were significantly correlated. Major trade-offs and synergies among services were between NPPact and water yield and regulation. Trade-off and synergy clusters showed that landscape functions depend on both natural and anthropogenic landscape patterns and processes.

Conclusions Providing transparent data about tradeoffs and synergies among landscape services can facilitate learning about which services are important among landscapes. For each of six settings we suggest action plans. We discuss the role of Iranian landscape stewardship and planning, and integrative research needs.

\section{P. Angelstam ( $\varangle)$}

School for Forest Management, Faculty of Forest Sciences, Swedish University of Agricultural Sciences (SLU), PO Box 43, 73921 Skinnskatteberg, Sweden e-mail: per.angelstam@slu.se

\section{P. Angelstam}

Department of Forestry and Wildlife Management, Inland

Norway University of Applied Sciences, Campus

Evenstad, N-2480 Koppang, Norway

A. Darvishi · M. Yousefi

Metropolitan Laboratory of Ecology and Territory of Barcelona, IERMB, Autonomous University of Barcelona, 08193 Bellaterra, Spain 
Keywords Ecosystem services · GIS - Landscape ecology $\cdot$ Social-ecological systems $\cdot$ Adaptive management $\cdot$ Spatial planning

\section{Introduction}

Maintaining landscapes as social-ecological systems, with their goods, services and values in the context of global change, is essential for human well-being and welfare (Naveh 2000; MEA 2005; IPBES 2019). In response to this, several parallel concepts have been developed over time. The ecosystem services (ES) concept was presented in the 1980s, within the context of biodiversity conservation (Bull et al. 2016), and refers to "the direct and indirect contributions of ecosystems to human well-being" (De Groot et al. 2010). ES is considered as an approach to highlight the societal dependence on ecological life-support systems. However, the ES concept has been criticized as a concept failing to include the complexity of both natural systems (Schröter et al. 2019) and socialecological systems (SES) (Angelstam et al. 2019). A SES is a complex of societal and ecological subsystems with mutual interactions (Biggs et al. 2015). This contrasts views that human-nature relations are either biocentric or anthropocentric, which tends to "fragment and take apart what in reality is whole" (Naveh 1988, p. 251). Thus, the ecosystem services framework may fail to explicitly tackle the complexity of social-ecological interactions, and neglects inherent landscape stewardship challenges (Angelstam et al. 2019). In contrast, the significance of understanding human-nature relationship is acknowledged in sustainability science (Ives et al. 2017) and environmental management (Walker-Springett et al. 2016).

To overcome theoretical and operational gaps of ES, the Landscape Service (LS) concept was proposed to support participatory landscape planning as a bridge between landscape ecology and sustainable development (Termorshuizen and Opdam 2009; Bastian et al. 2014). ES and LS are used synonymously in many cases (Lamarque et al. 2011), but they are not the same (Bastian et al. 2014). For example, ES and LS both appear as a boundary object for dealing with sustainability challenges (Termorshuizen and Opdam 2009). However, using LS instead of ES can be preferred for the sake of integrating scientists among disciplines, and practitioners, to encourage inter- and transdisciplinarity (Termorshuizen and Opdam 2009; Koschke et al. 2014). The differences between ES and LS emerge from the difference between ecosystem as a natural science phenomenon, and landscape as one integrating biophysical, anthropogenic and perceived dimensions of social-ecological systems (e.g., Angelstam et al. 2013). Additionally, LS has been considered to better address spatial heterogeneity in landscapes (Lamarque et al. 2011). Other features include the role of socio-economic and cultural values of human societies in landscapes. A wide range of methodologies have been applied for the identification and valuation of landscape services (Gulickx et al. 2013; Opdam 2020). Landscape services have been used mostly in cultural landscapes (Hermann et al. 2014), especially in Europe and North America by classification of landscape services to support local landscape planning (Vallés-Planells et al. 2014). Some studies have focused on both the landscape service concept and its practical relevance (Bastian et al. 2014).

Another more recent concept addressing the role of SES for humans is "Nature's Contributions to People" (NCP), which is used in the assessment by the Intergovernmental Science-Policy Platform on Biodiversity and Ecosystem Services (IPBES) (IPBES 2019). This framework recognizes the central and pervasive role that culture plays in defining all links between people and nature, and emphasized the role of indigenous and local knowledge in understanding NCP (Díaz et al. (2018). Some claim that there is no fundamental difference between NCP and ES (Costanza et al. 2017), and that ES already cover social sciences and other topics (Braat 2018). However, Peterson et al. (2018) argued that by replacing the term "ecosystem" by "nature", the NCP concept defocuses on the of role social-ecological processes in forming the world's ecosystems. Neither does it consider the ecosystems that are transformed by humans, such as urban and agricultural areas. Moreover, NCP emphasizes a one-directional flow from "nature" to "people", which ignores the complexity and nonlinearity of the coproduction and interwoven between nature and people. Although the role of multiple feedbacks and scales is recognized in the NCP framework (Díaz et al. 2018), it also emphasizes challenges raised also in the context of ES and LS (Müller et al. 2010). 
This study focuses on assessing states of socialecological systems using the concept landscape services. This includes three main challenges for the development towards sustainable landscapes (e.g., Antrop 2006; Zhou et al. 2019). First, due to the holistic character landscapes as SES, one challenge is to include landscape services provided by natural landscapes, as well as semi-natural, cultural and builtup landscapes dependent of anthropogenic interventions (Wu et al. 2013; Angelstam et al. 2013). Second, incorporating trade-offs and synergies between different landscape services to representing the interaction among multi-levelled services is needed (Birkhofer et al. 2015). Third, lack of planning and management systems to unify different disciplines and practice in order to improve frameworks like ES, NCP, and LS (Angelstam et al. 2019) can be a paramount challenge.

For landscape planning and decision-making objectives, it is important to understand all relevant landscape services, and bring in the interaction between them (Kandziora et al. 2013). While some landscapes provide single or a few services, other landscapes provide multiple services that influence each other (Egoh et al. 2008). Understanding interrelationships among services may help prevent unnecessary rivalry between different landscape services by paying attention to the most effective solutions to decrease the trade-offs or to increase synergies (Qiao et al. 2019). All landscape services can have an effect at all levels of a hierarchy, both directly and indirectly (Birkhofer et al. 2015), and are therefore important to consider in landscape stewardship and planning (Jia et al. 2014; Turkelboom et al. 2015). Estimating the states and trends of landscape services spatially can be used to reduce ecological impacts (Bai et al. 2011), and also be useful for social development (Mirzaei et al. 2019). However, despite the importance of estimating the provision of landscape service in spatial planning, each service alone cannot determine landscape characteristics (Kandziora et al. 2013). Therefore, once the portfolio of landscape services has been identified, synergies and trade-offs among them should be evaluated (Jia et al. 2014; Turkelboom et al. 2015).

This is particularly complex in regions with a long history of landscape uses, and with top-down decisionmaking legacies. Iran is well known as one of the oldest civilizations in the world (Rasoolimanesh et al
2013). Currently, Iran's spatial planning system has been affected by two phases of political revolutions, and long-term consequences of war (Amirahmadi 1986). Especially in the previous four decades, Iran has been affected by a symptom-based management approach (Madani 2014). Iranian researchers believe that the substantial issues of Iran especially regarding water security, land degradation, and loss of regional resources and capabilities to deliver landscape services, are grounded in decades of managerial myopia, as well as fragmented and top-down planning (Tavakoli et al 2018). National level ministries and organisations are the ones who have the visions, set the goals, and make the decisions. Management and planning organizations such as the Planning and Budget Organization, the Department of Environment, and the Iran Ministry of Roads \& Urban Development are responsible for environmental and spatial planning. They act independently and are solely responsible for the outcomes, whether being successful or failing. Recently, environmentalists mounted a formidable protest when the Ministry of Roads and Urban Development began implementing the new policy about road development in the Qazvin province. Environmental NGOs and academic communities claim that ecosystem services should be considered in the decision-making (Mousavi et al. 2020). The topdown and rigid planning in Iran establishes a tough condition for stakeholders to participate in the process of preparing and implementing plans. Moreover, lack of public participation, clear implementation mechanisms, coordination of national plan with local schemes, and local knowledge about the content and strategic vision of the plan are some of the reasons for the failure of spatial planning in Iran (Rasoolimanesh et al 2013). Government agencies also oppose implementation of costs to engage stakeholders, and instead make decisions based on national level social and economic interests regarding self-sufficiency in agriculture and industry or exports, without considering ecological capability and stakeholder engagement (Nikuee and Zibaee 2012; Azimi Dezfuli et al. 2017; Bakhshianlamouki et al. 2020). Usually, plans fail because the ecological condition or local stakeholders in the given area may not allow implementation (Rasoolimanesh et al 2013). These barriers in the current planning approach in Iran need to be modified into dynamic, flexible, and participatory adaptive plans. 
This calls for exploring new approaches, including mapping of landscape services in a concrete spatial planning unit at the regional level, such as the Iranian Qazvin province and its different landscape types. The landscape composition and structure of the Qazvin province has been formed by a long-term interaction between socio-economic, cultural and ecological structures that characterizes the bio-cultural regions in Iran (Darvishi et al. 2014a). Previous studies of landscape service in Iran have focused on service supply mapping, and landscape services hotspots have been identified by overlapping different services (Mousalou et al. 2020), mostly in urban landscapes (Ramyar 2019; Mousalou et al. 2020; Jahani and Barghjelveh 2021). The aim of this study is to assess levels, trade-offs and synergies of landscape services in the Iranian province of Qazvin, and to discuss barriers and bridges to include evidence-based knowledge in place-based planning towards sustainable landscapes (Zhou et al. 2019).

\section{Materials and methods}

Study area

Iran is a four-season country with distinct spring, summer, autumn and winter, and with steep gradients from high mountains, pastures and forests to deserts (Darvishi et al. 2015; Yousefi et al. 2021). This feature has created high habitat diversity with high species richness biodiversity and different human cultures (Darvishi et al. 2014b). This makes Iran an interesting case study for mapping LS, and in particular the Qazvin province $\left(15567 \mathrm{~km}^{2}\right.$; from $35^{\circ} 38^{\prime}$ to $36^{\circ} 82^{\prime} \mathrm{N}$ in latitude and from $48^{\circ} 73^{\prime}$ to $50^{\circ} 88^{\prime} \mathrm{E}$ in longitude) extending from 170 to $4100 \mathrm{~m}$ above sea level (Darvishi et al. 2020a). The northern part of Qazvin is mostly covered by natural areas on the Alborz Mountain. The central Qazvin plain has mostly been transformed to intensive agricultural and metropolitan areas (Yousefi et al. 2021). The southern part is mostly covered by dry farmland and pasture. The eastern part is desert. This diversity of landscapes makes the Qazvin province representative of the Middle East region (Panahi Fard and Mahvi 2018).

A total of $34 \%$ of the case study area is protected under various categories of conservation, including the three protected areas in the north and west, which compatible with IUCN (Francoise 2011) classification's categories (category VI: protected area with sustainable use of natural resources), called Alamoot, Tarom and Bashgol. Additionally, in two different areas named Abegarm-Avaj and Allah-Abad hunting is prohibited, which is a national classification. AllahAbad is considered as one of the most important habitats in the Middle East for the threatened MacQueen's Bustard (Chlamydotis macqueenii).

The Qazvin case study region has 1.24 million inhabitants, of which $75 \%$ are urban and $25 \%$ are rural. After recognition of Qazvin as a separate province in 1997, industrial and agricultural development has occurred at a fast pace. Thus, $2.8 \%$ of Iran's value added and $4.2 \%$ of investment have occurred in Qazvin while having 1.6\% of the country's population (Statistical Center of Iran 2016). Accordingly, the Qazvin province is one of the most important regions for food production and industrial development. At the same time as it suffers from lack of sufficient water, as well as soil and vegetation degradation (Mirzaei et al. 2019).

\section{Land covers and sampling design}

Following Nasiri et al. (2019) we used a hybrid method to classify Land Use and Land Cover (LULC) types by combining Google Earth maps and on-screen visual digitization of field data collected in 2018. Pastures and forests were extracted by classification of remote sensing data (Landsat 8 imagery) from 3 and 10 July 2018. Landsat images and the Digital Elevation Model (DEM) dataset were collected by the Department of Interior United States Geological Survey (USGS) (Zhumanova et al. 2018). Roads, rivers, irrigation network and well point shape files were prepared by the Urban Development and Agricultural Organization. In total 1345 hexagon sample cells (each cell $11 \mathrm{~km}^{2}$ ) have been identified which lying completely, or more than $95 \%$, within the Qazvin province borders (Fig. 1). To determine the hexagon sample cell sizes, we applied landscape composition and configuration metrics in different hexagon cell sizes. We tested for spatial thresholds by applying landscape metrics in different cell sizes (1, $2.5,5,7.5,10,12.5$, and $15 \mathrm{~km}^{2}$ ), and found that the variability of the landscape metrics did not change significantly beyond $11 \mathrm{~km}^{2}$. 
Selection of landscape services

We selected landscape service variables based on three criteria: (1) their relevance to the study area; (2) representing the five main hierarchical scales inspired by Barghjelveh et al. (2015) and presented in Table 1 (i.e., Physical Nature, Plant, Animal, Human, Society); and (3) the availability of data for the supply of landscape services. This selection provides a sufficient range of variation for the discussion of trade-offs and synergies, as well as implications for landscape stewardship and planning. The selected landscape services were (1) water yield; (2) water regulation; (3) pollination service; (4) actual Net Primary Production (NPPact); and (5) socio-cultural connectivity.
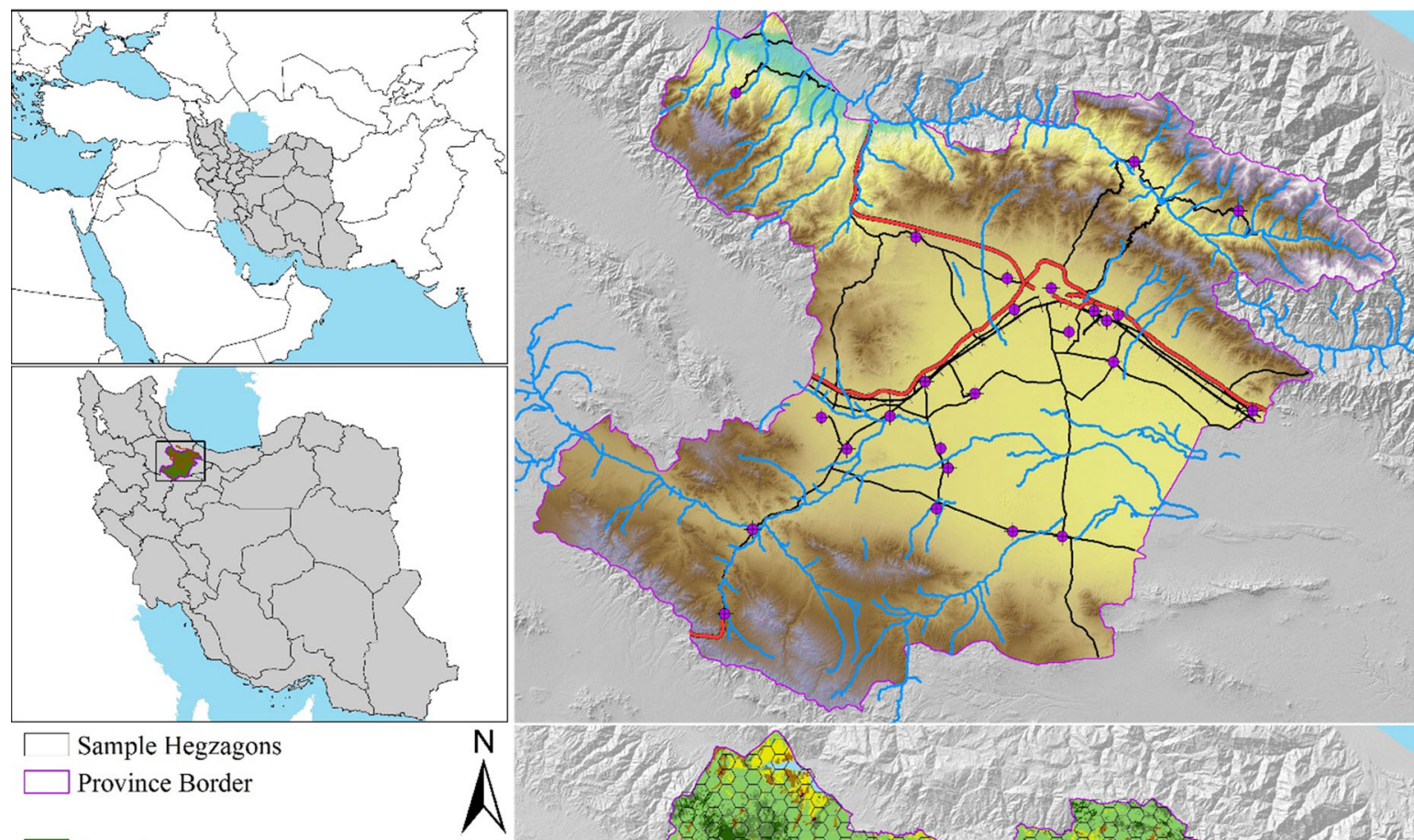

Forests

High-Density Pasture
Medium-Density Pastur
Low-Density Pasture
Semi-Deserts
Groves
Industrian Areas
Irrigated Farmlands
Dry Farmlands
Water Surfaces
Residential Arcas
Minings

Minings
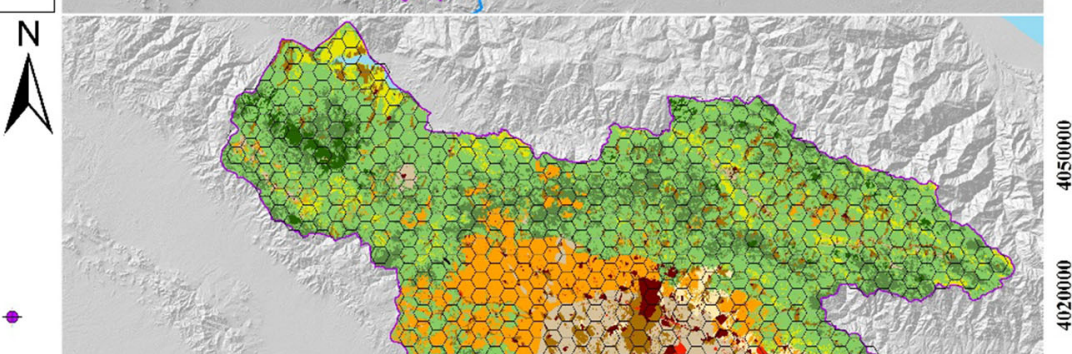

$80 \quad 40 \quad 0$ Kilometers

Main cities

River -

Highway

Main Roads

Rail Roads ++

Elevation

High : 4100

Low : 170



Fig. 1 Location of the Qazvin province in Iran, the topography, networks of rivers and built infrastructure, and a Land Use Land Cover (LULC) map in which high-, medium-, and low-density

pasture pixels have $>50 \%, 30-50 \%$, and $<30 \%$ cover of pastures, respectively 
The rationale for this selection is that water yield is affected by matter and energy cycling and is produced by the non-living part of landscape, thus representing the physical nature level of the hierarchy (Table 1), and of importance for service production at higher level (plants). Water regulation is maintained by living and non-living part of socio-ecological system, which has been affected directly by plants (current level), animals (higher level) and physical nature (lower level). To represent the third hierarchy level in this study we selected pollination. This was selected due to the direct relationship with plants and NPPact. As a fourth level service NPPact is consumed by both animals and society. This service has been produced by humannature relationships to meet social and ecological needs. Fifth, social-cultural connectivity as an influential factor in socioeconomic activities, and was selected due to growing demands through industrialization and mobility requirements in Qazvin province that increase social networks. This service can play a key role in landscape stewardship, planning and management.

Mapping and quantification of landscape services

\section{Water yield}

We modelled annual water yield as runoff using the InVEST Model (Sharp et al. 2015) and the water yield model presented by Redhead et al. (2016) (Eq. 1).

$Y(x)=\left(1-\frac{A E T(x)}{P(x)}\right) \times P(x)$

where $\mathrm{Y}(\mathrm{x})$ is the water yield for land use types on pixel $x, \operatorname{AET}(x)$ is the annual actual evapotranspiration for land use types on pixel $\mathrm{x} ; \mathrm{P}(\mathrm{x})$ is the annual precipitation on pixel $\mathrm{x}$.

Calculation of $\operatorname{AET}(\mathrm{x})$ is difficult in practice. Therefore, the InVEST model summarizes AET(x) to potential evapotranspiration $(\operatorname{PET}(\mathrm{x}))$, that has been used by Redhead et al (2016) (Eq. 2).

Table 1 Conceptualization of the hierarchical organisation of landscape services (LS) as a base for selection of indicators, and the key topic adaptive management for discussion of the Iranian context ( adapted from Barghjelveh et al. (2015))

\begin{tabular}{|c|c|c|c|c|c|c|c|}
\hline \multicolumn{2}{|l|}{ Concept } & \multirow{2}{*}{$\begin{array}{l}\text { Hierarchical } \\
\text { organization } \\
\text { Landscape }\end{array}$} & \multirow{2}{*}{$\begin{array}{l}\text { Level } \\
\text { structure } \\
\\
\text { Socio- } \\
\text { ecological } \\
\text { system }\end{array}$} & \multirow{2}{*}{$\begin{array}{l}\text { Level function } \\
\text { Co-evolution }\end{array}$} & \multirow{2}{*}{$\begin{array}{l}\text { Type of } \\
\text { services } \\
\text { Knowledge }\end{array}$} & \multirow{2}{*}{$\begin{array}{l}\text { Provider } \\
\text { Mind }\end{array}$} & \multirow{2}{*}{$\begin{array}{l}\text { The selected indicators are } \\
\text { shown in italics, and the } \\
\text { topic for discussion is } \\
\text { underlined } \\
\text { Adaptive management }\end{array}$} \\
\hline IHLS & & & & & & & \\
\hline \multirow[t]{5}{*}{ LS } & & Society & $\begin{array}{l}\text { Socio-spatial } \\
\text { environment }\end{array}$ & Purposive & $\begin{array}{l}\text { Socio- } \\
\text { spatial } \\
\text { service }\end{array}$ & $\begin{array}{l}\text { Social } \\
\text { organization }\end{array}$ & $\begin{array}{c}\text { Socio-Cultural } \\
\text { Connectivity }\end{array}$ \\
\hline & \multirow[t]{4}{*}{$\begin{array}{l}\text { ES } \\
\text { and } \\
\text { NCP }\end{array}$} & Human & $\begin{array}{l}\text { Open ended } \\
\text { symbolic } \\
\text { image }\end{array}$ & Consciousness & $\begin{array}{l}\text { Socio- } \\
\text { ecological } \\
\text { service }\end{array}$ & $\begin{array}{l}\text { Human and } \\
\text { Living } \\
\text { nature }\end{array}$ & Food Provision, NPPact \\
\hline & & Animal & $\begin{array}{l}\text { Innate } \\
\text { knowledge, } \\
\text { mobility }\end{array}$ & Autonomy & $\begin{array}{l}\text { Biophysical } \\
\text { service } \\
\text { (Survival) }\end{array}$ & Living nature & $\begin{array}{l}\text { Pollination, seed dispersal, } \\
\text { biological control, } \\
\text { medicinal resource, } \\
\text { nutrient cycling, } \\
\text { bioremediation }\end{array}$ \\
\hline & & Plant & $\begin{array}{c}\text { Fixed genetic } \\
\text { information }\end{array}$ & Preprogrammed & $\begin{array}{l}\text { Biophysical } \\
\text { service } \\
\text { (Survival) }\end{array}$ & $\begin{array}{l}\text { Living and } \\
\text { non-living } \\
\text { nature }\end{array}$ & $\begin{array}{l}\text { Water Regulation, habitat } \\
\text { provision, water } \\
\text { purification }\end{array}$ \\
\hline & & $\begin{array}{r}\text { Physical } \\
\text { Nature }\end{array}$ & $\begin{array}{c}\text { Mater and } \\
\text { energy }\end{array}$ & $\begin{array}{l}\text { Cycle of mater } \\
\text { and energy }\end{array}$ & $\begin{array}{r}\text { Physical } \\
\text { service }\end{array}$ & $\begin{array}{l}\text { Non-living } \\
\text { nature }\end{array}$ & Precipitation, water yield \\
\hline
\end{tabular}

Relations between the concepts landscape service (LS), ecosystem service (ES), nature's contributions to people (NCP), and integrated hierarchical landscape service (IHLS) are indicated in the first column 
$\frac{A E T(x)}{P(x)}=1+\frac{P E T(x)}{P(x)}-\left[1+\left(\frac{P E T(x)}{P(x)}\right)^{\omega}\right]^{1 / \omega}$

$\omega$ is an experimental parameter related to the plant available water content $(\mathrm{AWC}(\mathrm{x}))$, precipitation, and the constant $\mathrm{Z}$ which captures the local seasonality factor that presents the seasonal precipitation distribution and depths (Eq. 3).

$\Omega=\mathrm{Z} \frac{\mathrm{AWC}(\mathrm{x})}{\mathrm{P}(\mathrm{x})}+1.25$

For a more detailed description of the water yield model see Redhead et al. (2016).

\section{Water regulation}

Water regulation is a landscape service related to the ability of the water yield service components to store and retain water (Egoh et al. 2008). The ability of a landscape to regulate groundwater, soil capacity to water storage, and prevent floods and runoff depends on various factors, including the vegetation density, soil depth and type, slope and climate. We developed a Multi-Criteria Analysis (MCA) method following Comino et al. (2014) and Singh et al. (2017), using GIS modelling, to assess the water regulation service. MCA is useful for addressing the challenges related to ES trade-offs and synergies, and ecosystem service communication to planners and decision makers (Kremer et al. 2016). This capability is useful for understanding and evaluating socioecological relationships, and has been used and applied widely in environmental decision making and landscape planning (Comino et al. 2014; Kremer et al. 2016; Li et al. 2020). Vegetation density, soil depth and type, slope and climate, along with land use type data, were used for GIS-based regulation modelling to generate the potential water regulation map.

\section{Pollination}

The Millennium Ecosystem Assessment and TEEB classified pollination as a regulating ecosystem service (Schulp et al. 2014). Pollination affects crop production, and animal pollination affects more than $75 \%$ of global crop types, including vegetables, fruits, and some of the most important cash crops in Iran such as almonds (Díaz et al. 2019). Nearly 1000 species of bees in Iran are recognized as pollinators, most of them are from three families (Andrenidae, Apidae, Halictidae). Potential wild and domestic bee habitats were used for evaluating pollination (Hosseini et al. 2019). Natural and man-made landscape elements are basic habitats for bees, but also serve as stepping stones for bees to enter croplands, and provide foraging resources for bees additional to flowering crops (Öckinger and Smith 2007; Tscheulin et al. 2011). Following Burkhard et al. (2012) methodology the LULC map (Fig. 1) was used to quantify natural land cover patches (Öckinger and Smith 2007), and (2) farmland (Tscheulin et al. 2011) as bee habitats. Accordingly, we used the InVEST Model (Sharp et al. 2015) based on the LULC map, showing both natural and cultural landscapes (Eq. 4). For each bee families in every pixel in the landscape we estimated abundance based on nesting sites and flower availability obtained by expert opinion and expressed between 0 and 1, such that (Eq. 4).

$P S_{x \beta}=v_{0} P_{x \beta} \frac{\sum_{m=1}^{M} \frac{Y_{0 \beta m}}{P_{0 \beta m}} e^{\frac{-D_{m x}}{\alpha_{\beta}}}}{\sum_{m=1}^{M} e^{\frac{-D_{m x}}{\alpha_{\beta}}}}$

where $\mathrm{V}_{0}$ represents the crop value in farm cell o, $P_{x \beta}$ is the abundance index (0-1) for each families, $P_{0 \beta m}$ is abundance index of visiting bees at each agricultural land use cell, $Y_{0 \beta m}$ is expected yield of a crop in the pixel, $D_{m x}$ is the Euclidean distance between cells $\mathrm{m}$ and $\mathrm{x}$ and $\alpha_{\beta}$ is the expected foraging distance for the pollinator $\beta$.

\section{Actual net primary production (NPPact)}

The Net Primary Production (NPP) model was used to map landscape production service (NPPact). This has been defined as the capacity of landscape to produce the biomass in the different type of plant (Darvishi et al. 2020b). We used the LULC data (Fig. 1) to identify land use spatial distributions, a census from Planning and Budget Organization in the study area to identify NPP harvested, and additional information from the literature (Oerke et al. 1999; Guzmán et al. 2014). NPPact includes three main sub-indices, all of which were expressed as gigajoules using gross caloric value, following the method of Guzmán et al (2014). The first was the amount of energy in harvests of agricultural and rangeland crops (NPPh). The second was unharvested biomass (NPPuh) in the fields 
including weeds and part of the biomass that has been consumed by pests and wildlife depending on the type of crop, in agriculture or in pastures according to the study of Oerke et al (1999). The third was the total amount of energy harvested by humans and the amount of energy remaining in the landscape is calculated as NPPact (Eq. 5) (Darvishi et al. 2020b).

$N P P a c t=N P P h+N P P u h$

\section{Socio-cultural connectivity index}

Following the methods to estimate ecological connectivity presented by Darvishi et al. (2020c) we developed a socio-cultural connectivity (SCCa) index (Eq. 6) for assessment based on Socio-Cultural Functional Areas (SCFA). This model calculates cost distance analysis, which includes natural barriers effect, taking into consideration the type of barriers (LULC types), the range of distances and the type of LULC involved. The model was applied to the current LULC map. This index emphasizes the role played by the landscape matrix.

$S C C a=10-9\left[\operatorname{Ln}\left(1+x_{i}\right) / \operatorname{Ln}\left(1+x_{t}\right) 3\right]$

where $x_{i}$ is the value of the sum of the cost distance by pixel and $x_{t}$ is the maximum theoretical cost distance.

Finally, from this SCCa index we derived the absolute Socio-Cultural Connectivity (SCC), which implies the addition of all SCCa that had been calculated for the study area, according to the following expression:

$S C C=\sum_{m=1}^{m=n} \mathrm{SCCa} / \mathrm{m}$

where $\mathrm{m}$ is the number of SCFA considered.

Trade-off, synergy and cluster analyses

We employed an analytic hierarchy process to estimate the correlation between factors through pair-wise comparisons using Pearson correlation coefficient. Interactions were evaluated by service values in each hexagon raster cell against each other. Accordingly, the trade-off and synergy maps were made for the ten possible comparisons of landscape services. All the service values were standardized in SPSS between 1 and -1 ( 0 to 1 is high and 0 to -1 is low). In each pair-wise comparison, trade-off occurs where one service was high and another was low and synergy occurs where both services were high or low. By overlaying the two pair-wise maps, final spatially distinct clusters in the Qazvin province with most synergies and trade-offs among the landscape services was produced.

\section{Results}

Mapping of landscape services

Regarding water yield, it was higher in the northern and southern parts of Qazvin province compared to the centre (Fig. 2a). In the centre of study area, $662 \mathrm{~m}^{3} /$ $\mathrm{km}^{2}$ was the lowest water yield, and $86,122 \mathrm{~m}^{3} / \mathrm{km}^{2}$ in the northeast was the highest. Concerning water regulation, the central region of Qazvin province, where vegetation density and low slope is characteristic, was most effective (Fig. 2b). Low water regulation was found mainly in northern montane areas with shallow soil over bedrock and little opportunity for storage, as well as in the eastern deserts with low vegetation density and low water storage capacity. High values of pollination were obtained in the natural high-density pastures and forests as well as traditional farmlands (Fig. 2c). In contrast, low pollination was obtained where there was low density of vegetation and high density of industrial agricultures. Pollination was affected by vegetation in order to habitat provision as well as pesticides and herbicides usage to maximize landscape production. High biomass production (NPPact) as a landscape service was obtained in the centre of the Qazvin province, which is covered by intensive agricultures and groves (Fig. 2d). Low density pastures and semi-deserts located in the east and southeast of the study area had the lowest value of NPPact. High socio-cultural connectivity appeared in the centre of Qazvin province where the focus of urban development and road infrastructure is concentrated (Fig. 2e). Socio-cultural connectivity has a key role in the landscape in creating access for humans on the landscape which can lead to the realization of development programs and even the protection of natural areas. 




Fig. 2 Spatial distributions of the five landscape services a water yield, $\mathbf{b}$ water regulation, $\mathbf{c}$ pollination, $\mathbf{d}$ NPPact and $\mathbf{e}$ socio-cultural connectivity 
Fig. 3 Correlations among landscape services to identify trade-offs and synergies among Water Yield (WY), Water Regulation (WR), Pollination (PS), NPPact, and Socio-Cultural Connectivity (SCC)
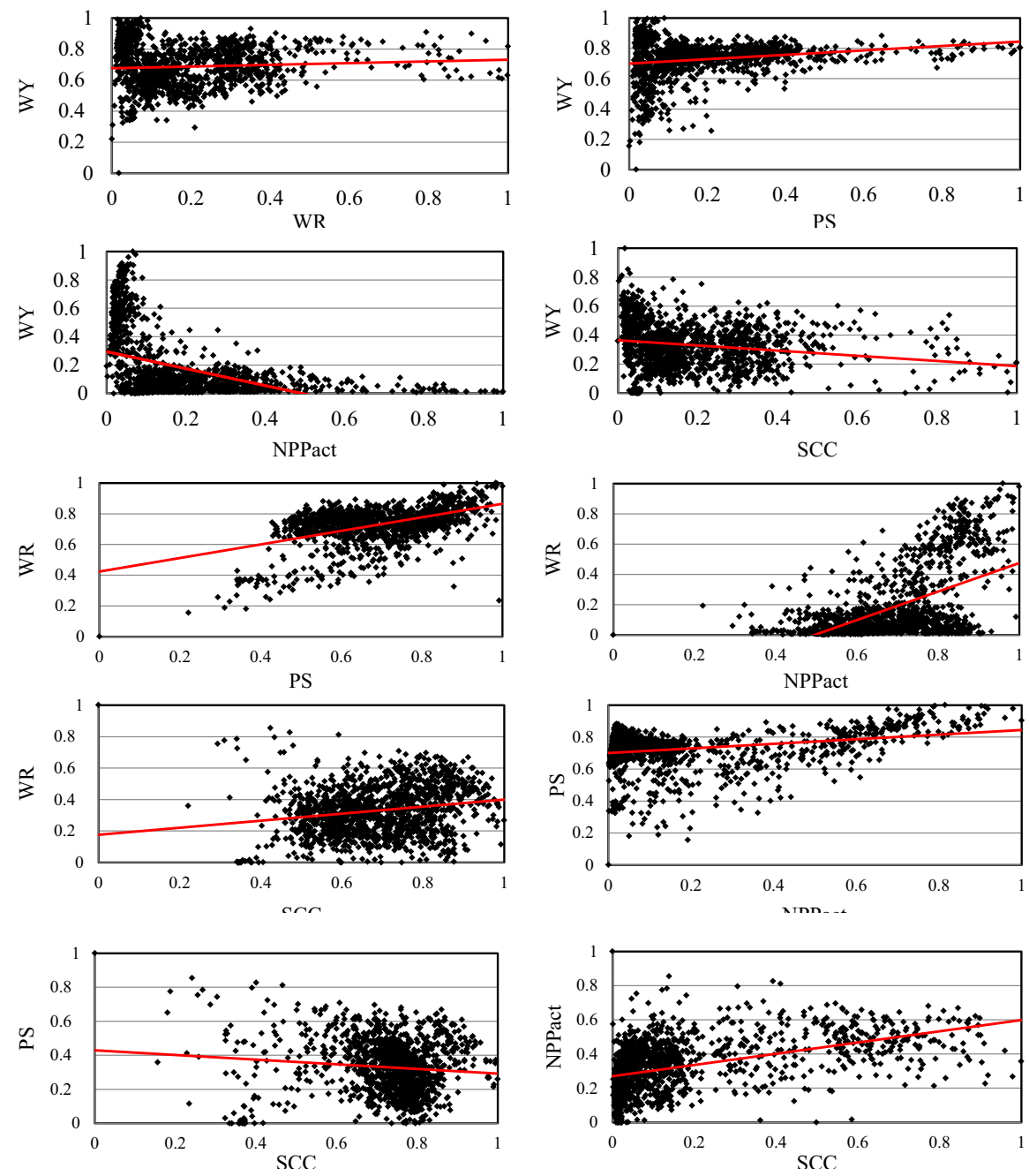

Table 2 Correlations among the landscape services analysed

\begin{tabular}{|c|c|c|c|c|c|}
\hline & Water yield & & & & \\
\hline Water yield & 1 & Water regulation & & & \\
\hline Water regulation & $0.068 *$ & 1 & Pollination & & \\
\hline Pollination & $0.203 * *$ & $0.489 * *$ & 1 & NPPact & \\
\hline NPPact & $-0.438 * *$ & $0.552 * *$ & $0.272 * *$ & 1 & Socio-cultural connectivity \\
\hline Socio-cultural connectivity & $-0.194 * *$ & $0.195 * *$ & $-0.107 * *$ & $0.489 * *$ & 1 \\
\hline
\end{tabular}

*Correlation is significant at the 0.05 level (2-tailed)

**Correlation is significant at the 0.01 level (2-tailed)

Correlations among landscape services

The various landscape services were evaluated systematically by comparing them to each other (Fig. 3).
Social-cultural connectivity, NPPact, pollination, water regulation, and water yield were found to have significant $(\mathrm{P}<0.0001)$ correlations with each other at different hierarchical levels (Table 2). By 


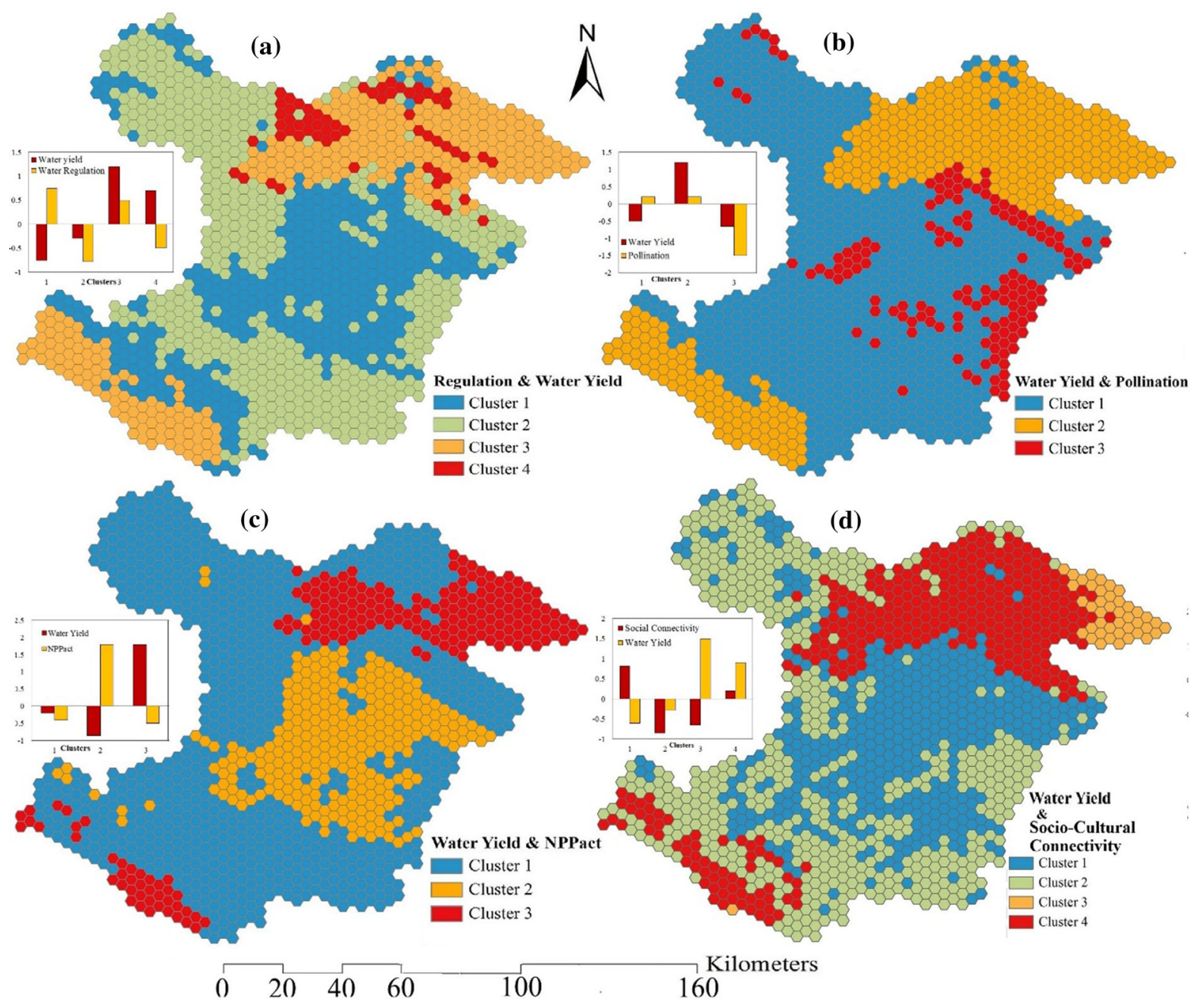

Fig. 4 Synergies and trade-offs between two paired clustering of landscape services in the Iranian Qazvin province

correlating spatially distributed information at the hexagon level among Qazvin landscapes, water yield showed low $\left(r^{2}<0.2\right)$ synergy $\left(r^{2}=0.068 *\right)$ with water regulation, moderate $\left(0.2<\mathrm{r}^{2}<0.4\right)$ synergy with pollination $\left(r^{2}=0.20 * *\right)$, high $\left(0.4<\mathrm{r}^{2}<0.6\right)$ trade-off with NPPact $\left(\mathrm{r}^{2}=-0.44 * *\right)$, and low tradeoff with socio-cultural connectivity $\left(\mathrm{r}^{2}=-0.19 * *\right)$ (Fig. 3 and Table 2). Correlation of water regulation with pollination and NPPact showed high synergy $\left(\mathrm{r}^{2}=0.49 * *\right.$ and $0.55^{* *}$, respectively), and low synergy with socio-cultural connectivity $\left(r^{2}=0.20^{* *}\right)$. Pollination had medium synergy with NPPact $\left(\mathrm{r}^{2}=0.27^{* *}\right)$ and low trade-off with socio-cultural connectivity $\left(r^{2}=-0.11^{* *}\right)$. One of the most important result of this study is the high synergy between
NPPact and socio-cultural connectivity $\left(r^{2}=0.49\right)$ (Fig. 3 and Table 2). According to Table 2 all landscape services, which showed spatially in Fig. 2, were significantly correlated to each other. NPPact had the highest and socio-cultural connectivity had the lowest correlation among the other services. With increasing NPPact and socio-cultural connectivity, water yield decreased. The highest correlation was between NPPact and water regulation.

Trade-offs and synergies among landscape services

We identified synergy and trade-off between all comparisons (Fig. 4a-j) which shows landscape 


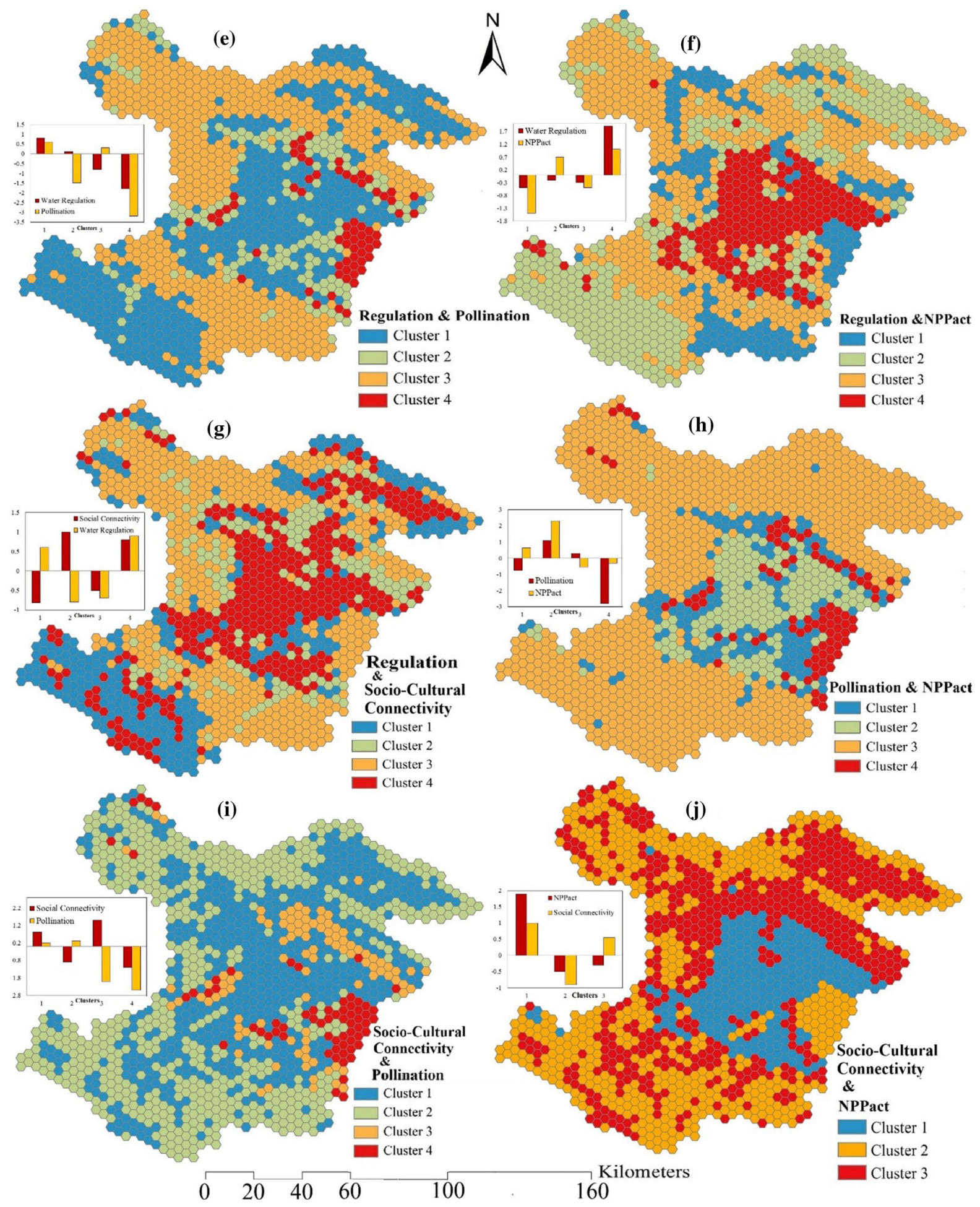

Fig. 4 continued 


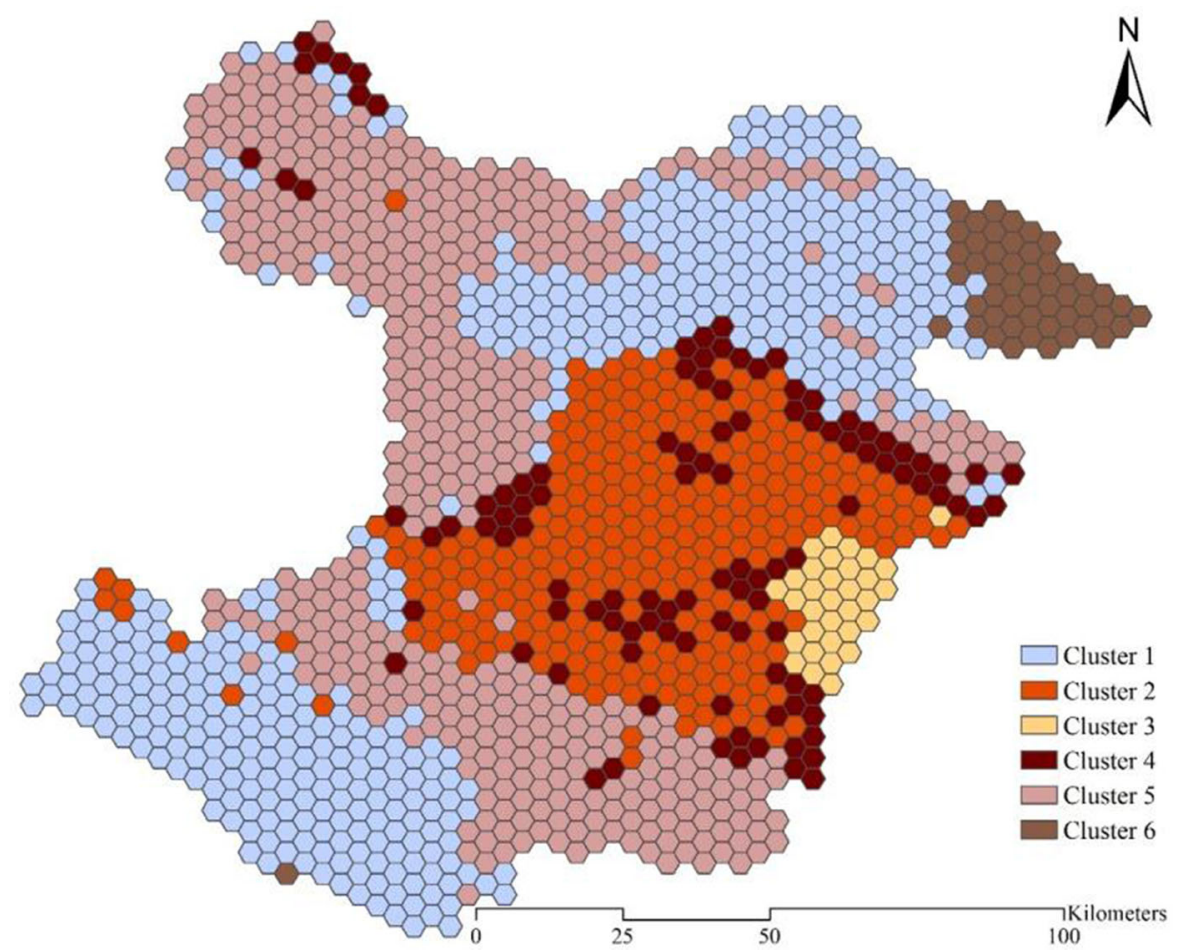

Fig. 5 Landscape topologies in the Qazvin province based on trade-offs and synergies among the landscape services analysed

function and service depends on landscape pattern. Each map demonstrates the spatial distributions of the two paired comparisons between two services. The values of each comparison were divided maximum into 4 clusters.

Figure 5 shows the final clusters, which can guide place-based adaptive management of landscape stewardship and planning. The properties of the landscape services and landscape compositions in each final cluster are shown in Table 3. It was identified that $59.7 \%$ of the cluster 1 contains pastures with $30.6 \%$ dry farmland which showed that most of this cluster covered by pasture-dry farmland mosaic. All landscape services in this cluster had high values, except NPPact.

Irrigated farmlands and groves constituted $63.3 \%$ and $15.1 \%$ of the cluster 2, respectively, and provided high NPPact and low pollination. In this cluster water yield was low and other landscape services were high. Inter-basin water transfer and deep well construction provided water for intensive irrigated farmland and groves. As a result, this cluster in terms of water security and scarcity is very sensitive.

Cluster 3 was a landscape with $94.2 \%$ of semidesert cover. In this cluster, all evaluated landscape services were low. Human activities in this cluster were limited by low capability of the landscape also forming the Allah-Abad hunting prohibited region.

Cluster 4 as an urbanization landscape with $34.2 \%$ of the urban and industrial areas) was covered by built infrastructures, and mixed with low density pastures, semi-deserts, and farmlands. High socio-cultural connectivity and low other landscape services showed this cluster fragmented by human and lost its capability to provide habitat and human level services.

Cluster 5 had the same landscape composition as cluster 1 ( $72.7 \%$ pastures and $19.4 \%$ dry farmland) but had low landscape services except pollination. Pastures constituted $90.0 \%$ of the cluster 6 which was the most natural landscapes but high water yield and low water regulation in this cluster is concerning. 
Table 3 Synergies and trade-offs in 6 clusters different of landscape services (LS), and Land Use Land Cover (LULC) proportions in each of them

\begin{tabular}{|c|c|c|c|c|c|c|}
\hline & $\begin{array}{l}\text { Clusters } \\
\text { C1 }\end{array}$ & $\mathrm{C} 2$ & $\mathrm{C} 3$ & $\mathrm{C} 4$ & $\mathrm{C} 5$ & C6 \\
\hline \multicolumn{7}{|l|}{ LS ( $\uparrow$ is high and $\downarrow$ is low) } \\
\hline Water Yield & $\uparrow$ & $\downarrow$ & $\downarrow$ & $\downarrow$ & $\downarrow$ & $\uparrow$ \\
\hline Water regulation & $\uparrow$ & $\uparrow$ & $\downarrow$ & $\downarrow$ & $\downarrow$ & $\downarrow$ \\
\hline Pollination & $\uparrow$ & $\downarrow$ & $\downarrow$ & $\downarrow$ & $\uparrow$ & $\uparrow$ \\
\hline NPPact & $\downarrow$ & $\uparrow$ & $\downarrow$ & $\downarrow$ & $\downarrow$ & $\downarrow$ \\
\hline Socio-cultural connectivity & $\uparrow$ & $\uparrow$ & $\downarrow$ & $\uparrow$ & $\downarrow$ & $\downarrow$ \\
\hline \multicolumn{7}{|l|}{ LULC (proportions in \%) } \\
\hline Forests & 0.5 & 0.0 & 0.0 & 2.1 & 1.3 & 1.8 \\
\hline Pastures1 & 9.8 & 0.0 & 0.0 & 0.7 & 8.7 & 22.6 \\
\hline Pastures2 & 43.0 & 0.6 & 0.1 & 5.4 & 44.5 & 60.3 \\
\hline Pastures 3 & 6.9 & 0.8 & 0.5 & 12.2 & 19.6 & 7.1 \\
\hline Semi-deserts & 1.1 & 8.9 & 94.2 & 30.5 & 0.7 & 0.0 \\
\hline Groves & 3.5 & 15.1 & 0.1 & 8.3 & 2.7 & 4.1 \\
\hline Irrigated farmlands & 2.6 & 63.3 & 2.8 & 13.1 & 1.4 & 0.9 \\
\hline Dry farmlands & 30.7 & 5.2 & 0.0 & 9.5 & 19.4 & 1.5 \\
\hline Water surface & 0.0 & 0.0 & 0.0 & 1.3 & 0.0 & 0.0 \\
\hline River & 0.3 & 0.3 & 0.6 & 0.4 & 0.1 & 0.3 \\
\hline Infrastructures & 2.3 & 5.8 & 1.8 & 16.6 & 1.8 & 1.3 \\
\hline Total area (ha) & 483,035 & 294,321 & 33,469 & 120,201 & 495,368 & 54,712 \\
\hline
\end{tabular}

\section{Discussion}

Trade-offs and synergies form landscape typologies

This case study demonstrates the feasibility of using transparent data about trade-offs and synergies among landscape services to showcase how evidence-based knowledge can be produced, and thus support learning about which services are important in different landscapes. The selection of five landscape services was made to stress the need to address the role of different hierarchical levels in social-ecological systems. Obviously a wide range of other services can be chosen, something that ought to be made jointly by representative stakeholders and actors in different place contexts.

Our findings on trade-offs and synergies among landscape services show that landscape composition has a significant effect on landscape function. All relationships between landscape services identified that both trade-off and synergy can be found across landscapes. High synergy between water yield and pollination was also found by Bai et al. (2011). The highest trade-off in this study appeared between water yield and NPPact, which was consistent with what has been found by Jia et al (2014), and in contrast to the findings of $\mathrm{Su}$ and $\mathrm{Fu}$ (2013). The discrepancy is due to the landscape composition effects. Because of high evaporation on the infrastructures, which appears more in high socio-cultural connectivity, water yield decreased by increasing the socio-cultural connectivity. We identified synergy between water regulation and other services. The highest synergy in this study obtained between water regulation and NPPact, also shown by Egoh et al (2008) who stressed that water regulation had a great impact on the agricultural sustainability in a landscape. Based on the literature review by Díaz et al. (2019), it was expected that the relationship between pollination and NPPact would be very high, but due to the high variation of landscape in the Qazvin province (intensive to traditional agriculture, high and low density of pasture, desert, and forest), moderate synergy has been obtained. Because of the existence of intensive agriculture in the study area as a result high biomass production and the relative low production of pastures, the balance is 
Table 4 Cluster description and appropriate action plans in hierarchical level as adaptive management

\begin{tabular}{|c|c|c|c|c|}
\hline Clusters & Cluster description & $\begin{array}{l}\text { Hierarchical } \\
\text { level }\end{array}$ & Action plan & References \\
\hline \multirow[t]{5}{*}{$\mathrm{C} 1$} & \multirow[t]{5}{*}{$\begin{array}{l}\text { Mixed farming with Low } \\
\text { efficiency }\end{array}$} & $\begin{array}{c}\text { Physical } \\
\text { nature }\end{array}$ & Contour plowing to soil conservation in steep slopes & $\begin{array}{l}\text { (Temesgen et al. } \\
\text { 2012) }\end{array}$ \\
\hline & & Plant & Optimization of the yield pattern & $\begin{array}{l}\text { (Karamouz et al. } \\
\text { 2010) }\end{array}$ \\
\hline & & Animal & Biological control & $\begin{array}{l}\text { (Birkhofer et al. } \\
\text { 2015) }\end{array}$ \\
\hline & & Human & Improvement in smallholder farmer knowledge & $\begin{array}{l}\text { (Nampanya } \\
\text { et al. 2012) }\end{array}$ \\
\hline & & Society & Contribution public participation & $\begin{array}{l}\text { (Razzaque } \\
\text { 2009) }\end{array}$ \\
\hline \multirow[t]{5}{*}{$\mathrm{C} 2$} & \multirow{5}{*}{$\begin{array}{l}\text { Human transformed } \\
\text { landscapes with low water } \\
\text { yield }\end{array}$} & $\begin{array}{c}\text { Physical } \\
\text { nature }\end{array}$ & Optimizing water use efficiency & $\begin{array}{l}\text { (Zhang et al. } \\
\text { 2017) }\end{array}$ \\
\hline & & Plant & Plants compatible with drought & (Blum 2005) \\
\hline & & Animal & Animal production systems, Biological control & $\begin{array}{l}\text { (Birkhofer et al. } \\
\text { 2015) }\end{array}$ \\
\hline & & Human & Using subsurface drip irrigation system & $\begin{array}{l}\text { (Parthasarathi } \\
\text { et al. 2018) }\end{array}$ \\
\hline & & Society & $\begin{array}{l}\text { Paying attention to smallholder farmers, Contribution } \\
\text { Public Participation to Better Water Management }\end{array}$ & $\begin{array}{l}\text { (Razzaque } \\
\text { 2009) }\end{array}$ \\
\hline \multirow[t]{5}{*}{$\mathrm{C} 3$} & \multirow[t]{5}{*}{ Semi-desert landscapes } & $\begin{array}{c}\text { Physical } \\
\text { nature }\end{array}$ & Soil stabilization operation & (Qi et al. 2020) \\
\hline & & Plant & Planting drought tolerant shrubs & \\
\hline & & Animal & livestock grazing management & $\begin{array}{l}\text { (Weber \& Horst } \\
\text { 2011) }\end{array}$ \\
\hline & & Human & Production energy from solar radiation & (Safriel 2009) \\
\hline & & Society & Ecotourism & $\begin{array}{l}\text { (Ryan and } \\
\text { Stewart 2009) }\end{array}$ \\
\hline \multirow[t]{5}{*}{$\mathrm{C} 4$} & \multirow{5}{*}{$\begin{array}{l}\text { Industrial and urban } \\
\text { landscapes with high SC } \\
\text { connectivity }\end{array}$} & $\begin{array}{r}\text { Physical } \\
\text { Nature }\end{array}$ & $\begin{array}{l}\text { Developing infrastructure by increasing surface } \\
\text { drainage }\end{array}$ & $\begin{array}{l}\text { (Boller et al. } \\
\text { 2019) }\end{array}$ \\
\hline & & Plant & Using acceptable green space and parks & $\begin{array}{l}\text { (Birkhofer et al. } \\
\text { 2015) }\end{array}$ \\
\hline & & Animal & Regard to the role of animal in carbon cycle & $\begin{array}{l}\text { (Schmitz et al. } \\
\text { 2018) }\end{array}$ \\
\hline & & Human & $\begin{array}{l}\text { Production capacity of rooftop gardens (RTGs) in } \\
\text { urban agriculture }\end{array}$ & $\begin{array}{l}\text { (Orsini et al. } \\
\text { 2014) }\end{array}$ \\
\hline & & Society & Urban services & $\begin{array}{l}\text { (Van Ryzin } \\
\text { 2004) }\end{array}$ \\
\hline \multirow[t]{5}{*}{$\mathrm{C} 5$} & \multirow[t]{5}{*}{$\begin{array}{l}\text { Mixed farming with low } \\
\text { capability }\end{array}$} & $\begin{array}{c}\text { Physical } \\
\text { nature }\end{array}$ & Soil improvement to increase water holding capacity & $\begin{array}{l}\text { (Batista et al. } \\
\text { 2018) }\end{array}$ \\
\hline & & Plant & Using dehydrated Crops & (Lea et al. 2004) \\
\hline & & Animal & Livestock grazing management & $\begin{array}{l}\text { (Weber and } \\
\text { Horst 2011) }\end{array}$ \\
\hline & & Human & Using manure instead of fertilizer & $\begin{array}{l}\text { (Ibrahim et al. } \\
\text { 2008) }\end{array}$ \\
\hline & & Society & Local farmer participation & $\begin{array}{r}\text { (Taylor and Van } \\
\text { Grieken 2015) }\end{array}$ \\
\hline
\end{tabular}


Table 4 continued

\begin{tabular}{|c|c|c|c|c|}
\hline Clusters & Cluster description & $\begin{array}{l}\text { Hierarchical } \\
\text { level }\end{array}$ & Action plan & References \\
\hline \multirow[t]{5}{*}{ C6 } & \multirow[t]{5}{*}{$\begin{array}{l}\text { Natural and sensitive } \\
\text { landscapes }\end{array}$} & $\begin{array}{c}\text { Physical } \\
\text { nature }\end{array}$ & Contour plowing to soil conservation in high slop & $\begin{array}{l}\text { (Temesgen et al. } \\
\text { 2012) }\end{array}$ \\
\hline & & Plant & Using of stabilizing plants to increase water regulation & \\
\hline & & Animal & $\begin{array}{l}\text { Exploiting based on pasture capacity and prevention } \\
\text { of overgrazing }\end{array}$ & $\begin{array}{l}\text { (Weber and } \\
\text { Horst 2011) }\end{array}$ \\
\hline & & Human & Identification of natural resources to management & $\begin{array}{l}\text { (Fraser et al. } \\
\text { 2006) }\end{array}$ \\
\hline & & Society & Tourism activity & $\begin{array}{l}\text { (Sánchez- } \\
\text { Cañizares } \\
\text { et al. 2018) }\end{array}$ \\
\hline
\end{tabular}

disturbed that have been shown in Fig. 3h where the sample units are concentrated in low NPPact and high pollination. Socio-cultural connectivity in the landscape can have a high impact on the NPPact by creating access (Monika et al. 2020). Access leads to intensive agricultural development and ultimately increases actual Net Primary Production.

Different clusters reflecting trade-offs and synergies show that landscape functions depend on the landscape structures. The severity of ecosystem services interactions was distinguishable across different LULC (Jia et al. 2014). For example, clustering Qazvin landscapes based on water yield and water regulation showed four different clusters. Landscapes with high water yield have a greater risk of flood and soil erosion, but availability of water regulation can improve such landscapes in the short term by large additions of stable organic materials (e.g., composts, biochar, and mulches), and in the long-term, building organic matter and aggregation will build porosity for storing water. This can be accomplished by reducing tillage, long-term cover cropping, rotating annual crops with diverse perennials, and generally keeping actively growing roots in the landscape (Sileshi et al. 2014). As a result, trade-off or low synergy between water yield and water regulation can cause flood and soil erosion.

Based on different clusters of landscape services six geographically distinct areas were identified. The results in the cluster 1 showed these landscapes have high capability to economic development, but there is low efficiency due to dry farming (Yousefi et al. 2020), so to compensate, action plans has been selected at all levels of the hierarchy to address low efficiency (See Table 4). For example, there is a growing body of observed evidence proposing that the best management actions, including agroforestry, nutrients balanced, conservation agriculture, and water management on smallholder farms (action plan proposed for human level) can enhance food production for the growing world population (Nath et al. 2018).

Intensively managed landscapes such as industrial agriculture in cluster 2 , as mentioned by Médiène et al (2011) and Birkhofer et al (2015), despite the high NPPact, often have simplified composition of serviceproviding units, accordingly, have low levels of ecological services such as pollination. In the agriculture landscapes, for example, farmlands provide the crop production but organize damaged and temporary habitats, while many species associated with pollination service depend on less damaged habitats in the landscape (Garibaldi et al. 2011). for instance, wild bees prefer semi-natural habitats (Garibaldi et al. 2013). Anthropogenic management is usually intensified (e.g., pesticide application) when they want to increase some service production (e.g., NPPact) and avoid loss of other services (biological control) (Birkhofer et al. 2015). Alternative management strategies by integrating natural services (biological control) to foster landscapes are an opportunity, which can increase NPPact sustainably and reduce dependence on anthropogenic interventions (Bommarco et al. 2013; Birkhofer et al. 2015).

The semi-desert landscape with maximum $200 \mathrm{~mm}$ precipitation, located in the eastern of Qazvin province, was identified as a separate cluster (Cluster 3). Here all landscape services had low values due to unsuitable soil and vegetation quality. This cluster has a good ability to develop ecotourism action due its 
specific and sensitive landscapes (Sánchez-Cañizares et al. 2018).

Cluster 4 was an urbanized landscape (34\% built-up areas) with fragmented natural habitats, which has negative effects on species that depend on large habitat patches (Kowarik 2011). Action plans in cluster 4 are in area of achieving sustainable cities and reducing landscape fragmentation. For instance, to reduce habitat fragmentation impacts, urban planning can assemble green infrastructures such as parks and street trees, which may benefit biodiversity and multiple ecosystem services (e.g., water regulation) (Birkhofer et al. 2015).

Cluster 5 has the same composition as cluster 1 but low capability. The results of the landscape services in this cluster shows soil and vegetation quality is low. The low water yield has more on the cause the ability of the landscape to be low in this cluster. Action plans selected to compensate this shortage.

High water yield and low water regulation in cluster 6 show sensitive landscape that need to be protected. Water production need to be regulated by vegetation but high slope and low-density vegetation made sensitive landscape in this cluster. Action plans in this cluster are set for the soil and water protection and sustainable production on the landscape.

Need for spatial planning and landscape stewardship

Information about different landscapes' capabilities for service production, their values and their sensitivities to impacts and spatial distribution is crucial for effective spatial planning. The existing impacts on these capabilities, and the objectives and guidelines for the spatial planning of the landscape, form a base for proposing action and development plans. We identified the capabilities of landscapes of the Qazvin province for service production and change over space and across different landscape compositions. Based on this we propose action plans for landscape services in each hierarchical level (Table 1) of each of six clusters with different landscape compositions (Table 4). We proposed soil conservation as action plan in the physical nature level to achieve sustainable soil retention in order to have more water drainage in the landscape. Optimization of the yield pattern would maximize water storage. Biological control in the level of animal can prevent the destruction of pollinators. Increasing farmer's knowledge would lead to a better understanding of sustainable agriculture at the human level of the hierarchy. Public participation can be involved at different scales, from village to region and country. Different levels of participation are reflected in socio-cultural connectivity at the society level.

Adaptive management and governance are key approaches for landscape stewardship of social-ecological systems under uncertainty (McLain and Lee 1996; Richardson et al. 2020). They involve cycles of problem definition, planning, implementing, monitoring and evaluating actions to learn and modify those actions by knowledge-sharing (Marmorek et al. 2019; Gillson et al. 2019). These actions should not only consider the socio-ecological system modelling to help minimize hazards of involuntary consequences, but also should validate conceptual models of landscape dynamics (Serrouya et al. 2019). However, critical challenges remain about whether adaptive management can lead to sustainable outcomes for both societal and ecological system. Previous adaptive management studies have tended to suffer from some shortcomings (Cinner et al. 2019). Many studies concentrate on either social or ecological perspective (Birkhofer et al. 2015). However, trade-offs between social and ecological domains can emerge. Hence, the integrated study of landscape service at different levels of hierarchy and adaptive management action plans based on trade-offs and synergies between social and ecological services can help solve this challenge. But what are the opportunities to using knowledge about landscape services in the Iranian planning context?

\section{Towards integrative research}

A simple and widely used method to support decisions and management strategies by identifying key factors is the analysis of strengths, weaknesses, opportunities and threats (SWOT) (Scolozzi et al. 2014; Bull et al. 2016). A SWOT analysis is useful for identifying knowledge gaps, can support decision making at different levels of hierarchy (Scolozzi et al. 2014), and suggest strategies for spatial planning and management. As an illustration of emerging insights that can support landscape management and policy-making process in different ways we made a SWOT analysis about ecological, spatial, and socio-cultural aspects of 
Table 5 List of strengths, weaknesses, opportunities, and threats of landscape services in the iranian qazvin region

\begin{tabular}{|c|c|c|}
\hline & Today & Tomorrow \\
\hline Positives & $\begin{array}{l}\text { Strengths: } \\
\text { - Large amount of agricultural biomass } \\
\text { - High potential for renewable energy } \\
\text { - High value of natural heritage, which favours } \\
\text { ecotourism development } \\
\text { - Areas with high natural value } \\
\text { - Habitat networks are functional } \\
\text { - Important transport corridor in northwest } \\
\text { Iran } \\
\text { - High proportion of protected areas (34\%) } \\
\text { - Concentration of urban and industrial } \\
\text { development in the province centre } \\
\text { - High socio-cultural connectivity } \\
\text { - Soil fertility is high } \\
\text { - High potential in grand water provision in } \\
\text { the centre of Qazvin province }\end{array}$ & $\begin{array}{l}\text { Opportunities: } \\
\text { - Benign climate for crop production } \\
\text { - Suitable areas for renewable energy development } \\
\text { - Proximity to the capital and megacity Tehran } \\
\text { - Support to habitat functioning from surrounding areas } \\
\text { - Ecosystem services provision in the surroundings } \\
\text { - The growing interest of youth and private sector in agriculture } \\
\text { - Existence of rivers in the north of the region } \\
\text { - Existence high biodiversity provision in the surroundings } \\
\text { - Export of landscapes services } \\
\text { - Diversity of cultures and ethnicities }\end{array}$ \\
\hline Negatives & $\begin{array}{l}\text { Weaknesses: } \\
\text { - Farming at steep slopes } \\
\text { - Lack of funding to invest in sustainable } \\
\text { water use development } \\
\text { - Lack of rivers always having water } \\
\text { - Loss of ecosystem services values } \\
\text { - Limited individual awareness for use of } \\
\text { biological control } \\
\text { - High amount of fertilizer use } \\
\text { - Changing smallholder farming to industrial } \\
\text { agriculture } \\
\text { - Ignoring public participation } \\
\text { - Low efficiency in water use } \\
\text { - Use of plants with high water consumption } \\
\text { - Flood irrigation system } \\
\text { - Insufficient infrastructure for soil protection } \\
\text { - Low awareness for energy savings } \\
\text { - Buildings are not constructed with } \\
\text { bioclimatic criteria } \\
\text { - Renewable energy business sector is weak } \\
\text { - Absence of financial mechanisms to pay for } \\
\text { landscape services }\end{array}$ & $\begin{array}{l}\text { Threats: } \\
\text { - Increasing environmental deterioration } \\
\text { - Excessive dependency on fossil fuels } \\
\text { - Risk for increased price of energy } \\
\text { - Environmental hazards threatens businesses or projects } \\
\text { - Proximity to the capital and megacity Tehran } \\
\text { - Hydrological risks } \\
\text { - Urbanization and industrialization in the centre } \\
\text { - Intensification of agriculture } \\
\text { - The government has prioritized agriculture, but without effective } \\
\text { support } \\
\text { - Limited consideration to landscape services } \\
\text { - Rapid changes in the preference, quality and standards of consumers } \\
\text { - Climate change effects leading to reduced precipitation, } \\
\text { desertification, soil salinization, erosion land subsidence } \\
\text { - Low income in smallholder community }\end{array}$ \\
\hline
\end{tabular}

Qazvin region landscapes (Table 5). The wide range of topics illustrate the need for integration of natural and social science disciplines on the one hand, and policymakers, planners and managers on the other. Examples of place-based integrative research topics are (1) analyses of legacies and current factors affecting the success or failure of planning strategies for sustaining landscape services, (2) better understanding of relationships among landscape services, (3) designate human resource allocation in order to implement planning strategies aiming at conservation of sensitive landscapes providing landscape services, (4) 
systematic analyses of habitat networks for biodiversity conservation among biogeographical regions, and (5) compare different landscapes' stakeholder profiles of landscape service benefits. To meet these challenges a paradigm shift from reductionist to holistic transdisciplinary research approaches that acknowledge the complexity of SES is needed (e.g., Naveh 2000). Inspiration for integrating knowledge production and learning among academic and non-academic actors can be found in landscape approaches involving integrative and transdisciplinary research (e.g., Angelstam et al. 2019). Landscape concepts and approaches reflect the need for integration of social-ecological systems, as well as patterns and processes operating across multiple spatial-temporal scales and organizational levels that influence the provision of landscape services (Klijn 1995; Angelstam et al. 2019).

\section{Conclusions}

This study focused on assessing different landscape services as a means of supporting landscape stewardship and planning. Different landscape service portfolios are subject to different trade-offs and synergies, and landscape functions depend on landscape structure. Integrating studies of landscape services at different levels of hierarchy, combined with adaptive management action plans that consider trade-offs and synergies, should be facilitated. The Qazvin province would be an appropriate place-based case study, which could be scaled up. However, the challenging topdown planning context in Iran requires encouragement of an evolution towards integrating knowledge production and learning among academic and nonacademic actors. Future studies should explore the dynamic trade-off and synergies analysis, and encourage integrative and transdisciplinary knowledge production and learning.

Acknowledgements This work was supported by the FORMAS Grant 2017:1342 to Per Angelstam.

Open Access This article is licensed under a Creative Commons Attribution 4.0 International License, which permits use, sharing, adaptation, distribution and reproduction in any medium or format, as long as you give appropriate credit to the original author(s) and the source, provide a link to the Creative Commons licence, and indicate if changes were made. The images or other third party material in this article are included in the article's Creative Commons licence, unless indicated otherwise in a credit line to the material. If material is not included in the article's Creative Commons licence and your intended use is not permitted by statutory regulation or exceeds the permitted use, you will need to obtain permission directly from the copyright holder. To view a copy of this licence, visit http://creativecommons.org/licenses/by/4.0/.

Funding Open access funding provided by Swedish University of Agricultural Sciences.

\section{References}

Amirahmadi H (1986) Regional planning in Iran: a survey of problems and policies. J Dev Areas 20(4):501-530

Angelstam P, Grodzynskyi M, Andersson K, Axelsson R, Elbakidze M, Khoroshev A, Kruhlov I, Naumov V (2013) Measurement, collaborative learning and research for sustainable use of ecosystem services: Landscape concepts and Europe as laboratory. Ambio 42(2):129-145

Angelstam P, Munoz-Rojas J, Pinto-Correia T (2019) Landscape concepts and approaches foster learning about ecosystem services. Landsc Ecol 34:1445-1460

Antrop M (2006) Sustainable landscapes: contradiction, fiction or utopia? Landsc Urban Plan 75(3-4):187-197

Azimi Dezfuli AA, Eftekhari AR, Nezamipur G, Hideg E (2017) A survey on integral futures studies capacity to overcome the challenge of meeting future water resources for food production at the national level in Iran. J Sustain Rural Dev 1(1):53-68

Bai Y, Zhuang C, Ouyang Z, Zheng H, Jiang B (2011) Spatial characteristics between biodiversity and ecosystem services in a human-dominated watershed. Ecol Complex $8(2): 177-183$

Bakhshianlamouki E, Masia S, Karimi P, van der Zaag P, Sušnik J (2020) A system dynamics model to quantify the impacts of restoration measures on the water-energy-food nexus in the Urmia lake Basin. Iran Sci Total Environ 708:134874

Barghjelveh S, Islami SY, Sayad N (2015) The logic of the "ecology of place", a model of thought for urban landscape development, case study: Tehran's Farahzad River-valley. Urban Ecosyst 18(4):1165-1186

Bastian O, Grunewald K, Syrbe RU, Walz U, Wende W (2014) Landscape services: the concept and its practical relevance. Landsc Ecol 29(9):1463-1479

Batista EM, Shultz J, Matos TT, Fornari MR, Ferreira TM, Szpoganicz B, de Freitas RA, Mangrich AS (2018) Effect of surface and porosity of biochar on water holding capacity aiming indirectly at preservation of the Amazon biome. Sci Rep-UK 8(1):1-9

Biggs R, Rhode C, Archibald S, Kunene LM, Mutanga SS, Nkuna N, Ocholla PO, Phadima LJ (2015) Strategies for managing complex social-ecological systems in the face of uncertainty: examples from South Africa and beyond. Ecol Soc. https://doi.org/10.5751/ES-07380-200152

Birkhofer K, Diehl E, Andersson J, Ekroos J, Früh-Müller A, Machnikowski F, Mader VL, Nilsson L, Sasaki K, Rundlöf M, Wolters V (2015) Ecosystem services-current 
challenges and opportunities for ecological research. Front Ecol Evol 2:87

Blum A (2005) Drought resistance, water-use efficiency, and yield potential-are they compatible, dissonant, or mutually exclusive? Aust J Agr Res 56(11):1159-1168

Boller D, Moy de Vitry M, Wegner JD, Leitão JP (2019) Automated localization of urban drainage infrastructure from public-access street-level images. Urban Water $\mathbf{J}$ 16(7):480-493

Bommarco R, Kleijn D, Potts SG (2013) Ecological intensification: harnessing ecosystem services for food security. Trends Ecol Evol 28(4):230-238

Braat LC (2018) Five reasons why the Science publication "Assessing nature's contributions to people" (Díaz, et al 2018) would not have been accepted in ecosystem services. Ecosyst Serv. https://doi.org/10.1016/j.ecoser.2018.02.002

Bull JW, Jobstvogt N, Böhnke-Henrichs A, Mascarenhas A, Sitas N, Baulcomb C, Lambini CK, Rawlins M, Baral H, Zähringer J, Carter-Silk E (2016) Strengths, weaknesses, opportunities and threats: a SWOT analysis of the ecosystem services framework. Ecosyst Serv 17:99-111

Burkhard B, Kroll F, Nedkov S, Müller F (2012) Mapping ecosystem service supply, demand and budgets. Ecol Indic 21:17-29

Cinner JE, Lau JD, Bauman AG, Feary DA, JanuchowskiHartley FA, Rojas CA, Barnes ML, Bergseth BJ, Shum E, Lahari R, Ben J (2019) Sixteen years of social and ecological dynamics reveal challenges and opportunities for adaptive management in sustaining the commons. P Natl Acad Sci USA 116(52):26474-26483

Comino E, Bottero M, Pomarico S, Rosso M (2014) Exploring the environmental value of ecosystem services for a river basin through a spatial multicriteria analysis. Land Use Policy 36:381-395

Costanza R, De Groot R, Braat L, Kubiszewski I, Fioramonti L, Sutton P, Farber S, Grasso M (2017) Twenty years of ecosystem services: How far have we come and how far do we still need to go?. Ecosyst Serv 28:1-16. http://dx.doi. org/https://doi.org/10.1016/j.ecoser.2017.09.008.

Darvishi A, Fakheran S, Soffianian AR, Ghorbani M (2015) Change detection and land use/cover dynamics in the arasbaran biosphere reserve. J Nat Environ 68(4):559-572 ((in Persian))

Darvishi A, Yousefi M, Dinan NM (2020b) Investigating the effect of Socio-economic disturbance resulting from human activities on landscape ecological function using HANPP index (Case Study: Qazvin Province). J Nat Environ 73(3):471-484

Darvishi A, Yousefi M, Marull J (2020) Modelling landscape ecological assessments of land use and cover change scenarios. Application to the Bojnourd Metropolitan Area (NE Iran). Land Use Policy. https://doi.org/10.1016/j. landusepol.2020.105098

Darvishi A, Ghorbani M, Fakheran S, Soffianian AR (2014b) Social-ecological systems, network analysis and key actors toward biodiversity and wildlife management (Case Study: Habitat of Caucasian Black Grouse, Arasbaran biosphere reserve), ijae 9: 29-40. (in Persian).

Darvishi A, Fakheran S, Soffianian AR, Ghorbani M (2014a) Quantifying landscape spatial pattern changes in the
Caucasian black grouse (Tetrao mlokosiewiczi) habitat in Arasbaran biosphere reserve. ijae 5: 27-37. (in Persian).

Darvishi A, Mobarghaee Dinan N, Barghjelveh S, Yousefi M (2020a) Assessment and spatial planning of landscape ecological connectivity for biodiversity management (Case Study: Qazvin Province). ijae 9(1):15-29

Díaz S, Pascual U, Stenseke M, Martín-López B, Watson RT, Molnár Z, Hill R, Chan KM, Baste IA, Brauman KA, Polasky S (2018) Assessing nature's contributions to people. Science 359(6373):270-272

Díaz SM, Settele J, Brondízio E, Ngo H, Guèze M, Agard J, Arneth A, Balvanera P, Brauman K, Butchart S, Chan K (2019) The global assessment report on biodiversity and ecosystem services of the Intergovernmental Science-Policy Platform on Biodiversity and Ecosystem Services. Summary for Policy Makers. URL: https://ipbes.net/ global-assessment.

Egoh B, Reyers B, Rouget M, Richardson DM, Le Maitre DC, van Jaarsveld AS (2008) Mapping ecosystem services for planning and management. Agric Ecosyst Environ 127(1-2):135-140

Francoise BG (2011) Guidelines for Protected Areas Legislation. IUCN. p. 147. ISBN 9782831712451.

Fraser ED, Dougill AJ, Mabee WE, Reed M, McAlpine P (2006) Bottom up and top down: Analysis of participatory processes for sustainability indicator identification as a pathway to community empowerment and sustainable environmental management. $\mathrm{J}$ Environ Manage 78(2):114-127

Garibaldi LA, Steffan-Dewenter I, Kremen C, Morales JM, Bommarco R, Cunningham SA, Carvalheiro LG, Chacoff NP, Dudenhöffer JH, Greenleaf SS, Holzschuh A (2011) Stability of pollination services decreases with isolation from natural areas despite honey bee visits. Ecol Lett 14(10):1062-1072

Garibaldi LA, Steffan-Dewenter I, Winfree R, Aizen MA, Bommarco R, Cunningham SA, Kremen C, Carvalheiro LG, Harder LD, Afik O, Bartomeus I (2013) Wild pollinators enhance fruit set of crops regardless of honey bee abundance. Science 339(6127):1608-1611

Gillson L, Biggs H, Smit IP, Virah-Sawmy M, Rogers K (2019) Finding common ground between adaptive management and evidence-based approaches to biodiversity conservation. Trends Ecol Evol 34(1):31-44

De Groot RS, Alkemade R, Braat L, Hein L, Willemen L (2010) Challenges in integrating the concept of ecosystem services and values in landscape planning, management and decision making. Ecol Complex 7(3):260-272

Gulickx MM, Verburg PH, Stoorvogel JJ, Kok K, Veldkamp A (2013) Mapping landscape services: a case study in a multifunctional rural landscape in The Netherlands. Ecol Ind 24:273-283

Guzmán G, Aguilera E, Soto D, Cid A, Infante J, Garcia-Ruiz R, Herrera C, Villa I, González de Molina M (2014) Methodology and conversion factors toestimate the net primary productivity of historical and contemporary agroecosystems (I). Sociedad Espãnola de Historia Agraria-Documentos Detrabajo 1407.

Hermann A, Kuttner M, Hainz-Renetzeder C, Konkoly-Gyuró É, Tirászi Á, Brandenburg C, Allex B, Ziener K, Wrbka T (2014) Assessment framework for landscape services in 
European cultural landscapes: an Austrian Hungarian case study. Ecol Ind 37:229-240

Hosseini Y, Monfared A, Haghani M (2019) A survey on Halictidae (Hymenoptera, Apoidea) species available in Iranian Pollinator Insects Museum of Yasouj University. J Insect Biodivers Syst 5(3):231-261

IPBES (2019) Global assessment report on biodiversity and ecosystem services of the Intergovernmental Science-Policy Platform on Biodiversity and Ecosystem Services. IPBES Secretariat, Bonn

Ibrahim M, Hassan A, Iqbal M, Valeem EE (2008) Response of wheat growth and yield to various levels of compost and organic manure. Pak J Bot 40(5):2135-2141

Ives CD, Giusti M, Fischer J, Abson DJ, Klaniecki K, Dorninger C, Laudan J, Barthel S, Abernethy P, Martin-López B, Raymond CM (2017) Human-nature connection: a multidisciplinary review. Curr Opin Environ Sustain 26:106-113. https://doi.org/10.1016/j.cosust.2017.05.005

Jahani N, Barghjelveh S (2021) Urban landscape services planning in an urban river-valley corridor system case study: Tehran's Farahzad River-valley landscape system. Environ Dev Sustain 1-21

Jia X, Fu B, Feng X, Hou G, Liu Y, Wang X (2014) The tradeoff and synergy between ecosystem services in the Grain-forGreen areas in Northern Shaanxi, China. Ecol Indic 43:103-113

Kandziora M, Burkhard B, Müller F (2013) Mapping provisioning ecosystem services at the local scale using data of varying spatial and temporal resolution. Ecosyst Serv $4: 47-59$

Karamouz M, Zahraie B, Kerachian R, Eslami A (2010) Crop pattern and conjunctive use management: a case study. Irrig Drain 59(2):161-173

Klijn JA (1995) Hierarchical concepts in landscape ecology and its underlying disciplines. DLO winand staring centre report, 100

Koschke L, van der Meulen S, Frank S, Schneidergruber A, Kruse M, Fürst C, Neubert E, Ohnesorge B, Schröder C, Müller F, Bastian O (2014) Do you have 5 minutes to spare?-The challenges of stakeholder processes in ecosystem services studies. LO 37:1-25

Kowarik I (2011) Novel urban ecosystems, biodiversity, and conservation. Environ Pollut 159(8-9):1974-1983

Kremer P, Hamstead ZA, McPhearson T (2016) The value of urban ecosystem services in New York City: A spatially explicit multicriteria analysis of landscape scale valuation scenarios. Environ Sci Policy 62:57-68

Lamarque P, Quetier F, Lavorel S (2011) The diversity of the ecosystem services concept and its implications for their assessment and management. C R Biol 334(5-6):441-449

Lea PJ, Parry MAJ, Medrano H (2004) Improving resistance to drought and salinity in plants. Ann Appl Biol 144:249-250

Li F, Guo S, Li D, Li X, Li J, Xie S (2020) A multi-criteria spatial approach for mapping urban ecosystem services demand. Ecol Indic 112:106119

MEA (2005) Ecosystems and human well-being: synthesis. Island Press, Washington, DC, p 137

Madani K (2014) Water management in Iran: what is causing the looming crisis? J Environ Studies Sci 4(4):315-328

Marmorek D, Nelitz M, Eyzaguirre J, Murray C, Alexander C (2019) Adaptive management and climate change adaptation: two mutually beneficial areas of practice. JAWRA 55(4):881-905

McLain RJ, Lee RG (1996) Adaptive management: promises and pitfalls. Environ Manage 20(4):437-448

Mirzaei M, Yazdani S, Nazari MR, Mahmoodi A, Yavari G, Fadaei MS (2019) Agricultural economic and environmental impacts of water resources management scenarios of agricultural sector in Qazvin Plain. Int J Agric Manage Dev 9:55-65

Monika E, Nakisha F, Anderson EC, Mysha C (2020) Socioecological connectivity differs in magnitude and direction across urban landscapes. Sci Rep. https://doi.org/10.1038/ s41598-020-61230-9

Mousalou M, Darabi H, Ehsani AH (2020) Assessment of landscape services in suburban area of Eastern Saleh Abad, South of Tehran. J Rural Res 11(3):440-453

Mousavi SA, Ghahfarokhi MS, Koupaei SS (2020) Negative impacts of nomadic livestock grazing on common rangelands' function in soil and water conservation. Ecol Indic 110:105946

Médiène $\mathrm{S}$, Valantin-Morison $\mathrm{M}$, Sarthou JP, De Tourdonnet $\mathrm{S}$, Gosme M, Bertrand M, Roger-Estrade J, Aubertot JN, Rusch A, Motisi N, Pelosi C (2011) Agroecosystem management and biotic interactions: a review. Agron Sustain Dev 31(3):491-514

Müller F, de Groot R, Willemen L (2010) Ecosystem services at the landscape scale: the need for integrative approaches. LO 23, 1-11. https://orcid.org/0000-0002-5023-5575.

Nampanya S, Suon S, Rast L, Windsor PA (2012) Improvement in smallholder farmer knowledge of cattle production, health and biosecurity in southern Cambodia between 2008 and 2010. Transbound Emerg Dis 59(2):117-127

Nasiri V, Darvishsefat AA, Rafiee R, Shirvany A, Hemat MA (2019) Land use change modeling through an integrated multi-layer perceptron neural network and Markov chain analysis (case study: Arasbaran region, Iran). J For Res 30(3):943-957

Nath AJ, Lal R, Sileshi GW, Das AK (2018) Managing India's small landholder farms for food security and achieving the "4 per Thousand" target. Sci Total Environ 634:1024-1033

Naveh Z (1988) Biocybernetic perspectives of landscape ecology and management. In: Moss MR (ed), Landscape ecology and management. Polyscience Publications Inc., Montreal, pp 23-34

Naveh Z (2000) What is holistic landscape ecology? A conceptual introduction. Landsc Urban Plan 50(1-3):7-26

Nikuee A, Zibaee M (2012) Water resource management and food security in Zayande Rud basin: application of integrated analysis of river basin. Agricu Econ Dev Agric Sci Technol 26(3):183-196 (In Persian)

Oerke E, Dehne H, Schönbeck F, Weber A (1999) Crop production and crop protection: estimated losses in major food and cash crops. Elsevier, Amsterdam

Opdam P (2020) Implementing human health as a landscape service in collaborative landscape approaches. Landsc Urban Plan 199:103819

Orsini F, Gasperi D, Marchetti L, Piovene C, Draghetti S, Ramazzotti S, Bazzocchi G, Gianquinto G (2014) Exploring the production capacity of rooftop gardens (RTGs) in urban agriculture: the potential impact on food 
and nutrition security, biodiversity and other ecosystem services in the city of Bologna. Food Secur 6(6):781-792

Panahi Fard M, Mahvi AH (2018) Baseline Monitoring of Total Organic Carbon (TOC) in water resources and Soil of Qazvin plain. Dissertation, Qazvin University of Medical Sciences.

Parthasarathi T, Vanitha K, Mohandass S, Vered E (2018) Evaluation of drip irrigation system for water productivity and yield of rice. Agron J 110(6):2378-2389

Peterson GD, Harmáčková ZV, Meacham M, Queiroz C, Jiménez-Aceituno A, Kuiper JJ, Malmborg K, Sitas N, Bennett EM (2018) Welcoming different perspectives in IPBES. Ecol Soc. https://doi.org/10.5751/ES-10134230139

Qi Y, Chen T, Shukla MK, Chang Q (2020) Using soil minerals to investigate desert expansion in northern Shaanxi Province. China Aeolian Res 43:100577

Qiao X, Gu Y, Zou C, Xu D, Wang L, Ye X, Yang Y, Huang X (2019) Temporal variation and spatial scale dependency of the trade-offs and synergies among multiple ecosystem services in the Taihu Lake Basin of China. Sci Total Environ 651:218-229

Ramyar R (2019) Social-ecological mapping of urban landscapes: Challenges and perspectives on ecosystem services in Mashhad, Iran. Habitat Int 92:102043

Rasoolimanesh M, Jaafar M, Badarulzaman N (2013) Urban planning and management system in iran: a review and assessment. Middle-East J Sci Res 18(2):220-229

Razzaque J (2009) Public participation in water governance. In: The evolution of the law and politics of water. Springer Dordrecht, pp 353-371

Redhead JW, Stratford C, Sharps K, Jones L, Ziv G, Clarke D, Oliver TH, Bullock JM (2016) Empirical validation of the InVEST water yield ecosystem service model at a national scale. Sci Total Environ 569:1418-1426

Richardson S, Mill AC, Davis D, Jam D, Ward AI (2020) A systematic review of adaptive wildlife management for the control of invasive, non-native mammals, and other human-wildlife conflicts. Mamm Rev 50(2):147-156

Ryan C, Stewart M (2009) Eco-tourism and luxury-the case of Al Maha. Dubai J Sustain Tour 17(3):287-301

Van Ryzin GG (2004) Expectations, performance, and citizen satisfaction with urban services. J Policy Anal Manage 23(3):433-448

Safriel U (2009) Deserts and desertification: challenges but also opportunities. Land Degrad Dev 20(4):353-366

Schmitz OJ, Wilmers CC, Leroux SJ, Doughty CE, Atwood TB, Galetti M, Davies AB, Goetz SJ (2018) Animals and the zoogeochemistry of the carbon cycle. Science. https://doi. org/10.1126/science.aar3213

Schröter M, Ring I, Schröter-Schlaack C, Bonn A (2019) The Ecosystem Service Concept: Linking Ecosystems and Human Wellbeing. In: Atlas of ecosystem services. . Springer, Cham, pp 7-11 https://doi.org/10.1007/978-3319-96229-0_2.

Schulp CJE, Lautenbach S, Verburg PH (2014) Quantifying and mapping ecosystem services: demand and supply of pollination in the European Union. Ecol Indic 36:131-141

Scolozzi R, Schirpke U, Morri E, D'Amato D, Santolini R (2014) Ecosystem services-based SWOT analysis of protected areas for conservation strategies. J Environ Manage 146:543-551

Serrouya R, Seip DR, Hervieux D, McLellan BN, McNay RS, Steenweg R, Heard DC, Hebblewhite M, Gillingham M, Boutin S (2019) Saving endangered species using adaptive management. P Natl Acad Sci USA 116(13):6181-6186

Sharp R, Tallis HT, Ricketts T, Guerry AD, Wood SA, ChaplinKramer R, Nelson E, Ennaanay D, Wolny S, Olwero N (2015) In: VEST Version 3.2. 0 User's Guide. The natural capital project. The nature conservancy, and world wildlife fund

Sileshi GW, Mafongoya PL, Akinnifesi FK, Phiri E, Chirwa P, Beedy T, Makumba W, Nyamadzawo G, Njoloma J, Wuta M, Nyamugafata P (2014) Agroforestry: fertilizer trees. Encycl Agric Food Syst 1:222-234

Singh LK, Jha MK, Chowdary VM (2017) Multi-criteria analysis and GIS modeling for identifying prospective water harvesting and artificial recharge sites for sustainable water supply. J Clean Prod 142:1436-1456

Statistical Center of Iran (SCIR) (2016) https://www.amar.org. ir/english.

Su C, Fu B (2013) Evolution of ecosystem services in the Chinese Loess Plateau under climatic and land use changes. Glob Planet Change 101:119-128

Sánchez-Cañizares SM, Castillo-Canalejo AM, CabezaRamírez LJ (2018) Sustainable tourism in sensitive areas: Bibliometric characterisation and content analysis of specialised literature. Sustainability 10(5):1525

Tavakoli M, Ebrahimi A, Hamidi S (2018) Analysis of Iran spatial planning zoning pattern from post-Constitutional Revolution till present. Spatial Plann 22(1):143-179

Taylor BM, Van Grieken M (2015) Local institutions and farmer participation in agri-environmental schemes. J Rural Stud 37:10-19

Temesgen M, Uhlenbrook S, Simane B, Van Der Zaag P, Mohamed Y, Wenninger J, Savenije HHG (2012) Impacts of conservation tillage on the hydrological and agronomic performance of Fanya juus in the upper Blue Nile (Abbay) river basin. Hydrol Earth Syst Sci 16(12). https://doi.org/ 10.5194/hess-16-4725-2012.

Termorshuizen JW, Opdam P (2009) Landscape services as a bridge between landscape ecology and sustainable development. Landsc Ecol 24(8):1037-1052

Tscheulin T, Neokosmidis L, Petanidou T, Settele J (2011) Influence of landscape context on the abundance and diversity of bees in Mediterranean olive groves. Bull Entomol Res 101(5):557

Turkelboom F, Thoonen M, Jacobs S, Berry P (2015) Ecosystem service trade-offs and synergies. Ecol Soc 21(1):43

Vallés-Planells M, Galiana F, Van Eetvelde V (2014) A classification of landscape services to support local landscape planning. Ecol Soc 19(1)

Walker-Springett K, Jefferson R, Böck K, Breckwoldt A, Comby E, Cottet M, Hübner G, Le Lay YF, Shaw S, Wyles K (2016) Ways forward for aquatic conservation: Applications of environmental psychology to support management objectives. J Environ Manage 166:525-536

Weber KT, Horst S (2011) Desertification and livestock grazing: the roles of sedentarization, mobility and rest. Pastoralism Res Policy Pract 1(1):1-11 
Wu J, Feng Z, Gao Y, Peng J (2013) Hotspot and relationship identification in multiple landscape services: a case study on an area with intensive human activities. Ecol Indic 29:529-537

Yousefi M, Darvishi A, Padró R, Barghjelveh S, Dinan NM, Marull J (2020) An energy-landscape integrated analysis to evaluate agroecological scarcity. Sci Total Environ 739:139998

Yousefi M, Darvishi A, Tello E, Shahindokht B, Dinan NM, Marull J (2021) Comparison of two biophysical indicators under different landscape complexity. Ecol Indic 124:107439

Zhang G, Liu C, Xiao C, Xie R, Ming B, Hou P, Liu G, Xu W, Shen D, Wang K, Li S (2017) Optimizing water use efficiency and economic return of super high yield spring maize under drip irrigation and plastic mulching in arid areas of China. Field Crops Res 211:137-146
Zhou BB, Wu J, Anderies JM (2019) Sustainable landscapes and landscape sustainability: a tale of two concepts. Landsc Urban Plan 189:274-284

Zhumanova M, Mönnig C, Hergarten C, Darr D, Wrage-Mönnig N (2018) Assessment of vegetation degradation in mountainous pastures of the Western Tien-Shan, Kyrgyzstan, using eMODIS NDVI. Ecol Indic 95:527-543

Öckinger E, Smith HG (2007) Semi-natural grasslands as population sources for pollinating insects in agricultural landscapes. J Appl Ecol 44(1):50-59

Publisher's Note Springer Nature remains neutral with regard to jurisdictional claims in published maps and institutional affiliations. 